\title{
SISTEM INFORMASI PELAPORAN DAN PENCATATAN AKTIFITAS KEGIATAN HUTAN DI TAMAN NASIONAL GUNUNG CIREMAI BERBASIS IMAGE GEOTAGGING
}

\author{
Iwan Lesmana ${ }^{1}$, Yati Nurhayati ${ }^{2}$ \\ Fakultas Ilmu Komputer Universitas Kuningan \\ Jalan Cut Nyak Dhien No.36A Cijoho Kuningan \\ Email : iwanlesmana@uniku.ac.id, yati.nurhayati@uniku.ac.id
}

\begin{abstract}
Kemajuan Teknologi informasi sekarang ini khususnya telepon selular yang telah menjadi suatu peralatan yang dapat mempermudah penyebaran maupun penyampaian informasi dari satu pihak ke pihak lain. Konsep geotagging sangat mirip dengan menandai titik pada alat GPS, pada geotagging tidak hanya menambahkan titik arah tetapi menambahkan pula informasi metadata spasial ke dalam media digital atau foto Proses aktifitas pelaporan dan pencatatan sekarang masih menggunakan proses manual baik tercatat maupun tidak tercatat dan belum adanya sistem untuk menyimpan proses pelaporan tersebut. Desain sistem dalam penelitian ini berupa sistem informasi yang bisa diakses public berupa pelaporan image geotagging pada aplikasi android (.apk) dan pengelolaan terpadu oleh Balai TNGC. Capaian atau target penelitian yang ingin dicapai adalah adanya kemudahan penyampaian informasi dari masyarakat atau petugas TNGC dalam hal pelaporan dan pencatatan aktifitas hutan serta keinginan penulis diharapkan penelitian ini menjadi pilot atau acuan yang bisa dipakai oleh seluruh Taman Nasional yang ada di Indonesia. Pengembangan sistem pada penelitian ini menggunakan metode Extreme Programing (XP), dimana metode ini cocok pada permasalahan yang ada. Untuk pemodelan perancangan menggunakan UML (Unified Modelling Language.
\end{abstract}

Kata Kunci : TNGC;Geotagging; Android; Extreme Programing; UML

Current advances in information technology, especially cellular phones, have become tools that can facilitate the dissemination and delivery of information from one party to another. The concept of geotagging is very similar to marking points on GPS devices, geotagging not only adds waypoints but also adds spatial metadata information to digital media or photos. The process of reporting and recording activities is still using manual processes, both recorded and unrecorded and there is no system for save the reporting process. The system design in this study is an information system that can be accessed by the public in the form of reporting geotagging images on an android application (.apk) and integrated management by Balai TNGC. Achievements or research targets to be achieved are the ease of delivery of information from the community or TNGC officers in terms of reporting and recording of forest activities and the wishes of the authors are expected to be a pilot or reference that can be used by all National Parks in Indonesia. The system development in this study uses the Extreme Programing (XP) method, where this method is suitable for the existing problems. For modeling design using UML (Unified Modeling Language.

Keywords: TNGC; Geotagging; Android; Extreme Programing; UML

\section{Pendahuluan}

Kemajuan Teknologi informasi sekarang ini khususnya telepon selular yang telah menjadi suatu peralatan yang dapat mempermudah penyebaran maupun penyampaian informasi dari satu pihak ke pihak lain. Perkembangan teknologi telepon selular juga diikuti dengan kemampuan sistem operasi sebagai perangkat lunak. Salah satu sistem operasi pada telepon selular yang cukup berkembang pesat antara lain adalah Android. Android adalah sebuah sistem operasi multiplatform yang bersifat open source. Sejak awal munculnya Android sangat mengalami 
JURNAL NUANSA INFORMATIKA

Volume 14 Nomor 1, Januari 2020

perkembangan yang sangat pesat dan banyak digemari oleh penggunanya karena kemudahan penggunaan dan fleksibel pada telepon selular.

Kemunculan smartphone sejak tahun 2007 menjadikan berbagai kalangan masyarakat bisa memilki ponsel cerdas disamping harga yang murah tetapi didukung dengan teknologi yang handal. Pada smartphone generasi ke dua (iphone 3G, HTC dsb) teknologi foto geotagging sudah tertanam pada smartphone tersebut. Pada penelitian yang dilakukan oleh Lou et al (2011) yang bejudul "The relative ease and accessibility of geotagging has "generated a wave of geo-awareness", menyatakan bahwa semua pengguna smartphone menawarkan model yang memungkinkan upload foto geotag, video bahkan pesan teks secara instan ke berbagai macam situs seperti Flickr, Youtube dan Twiter.

Konsep geotagging sangat mirip dengan menandai titik pada alat GPS, pada geotagging tidak hanya menambahkan titik arah tetapi menambahkan pula informasi metadata spasial ke dalam media digital atau foto. Pada umumnya foto adalah yang sering digunakan untuk media geotag, namun pada beberapa tahun terakhir penggunaan geotag tidak hanya pada foto saja tetapi berkembang ke media lain seperti video dan web (misalnya Twitter). Alat GPS genggam seperti Garmin Etrex, Magellan Tomtom Go dan lainnya telah sering digunakan selama beberapa tahun untuk penjelajahan lapangan (Fletcher et al., 2003). Salah satu metode yang digunakan dalam penelitian ini adalah sensor GPS yang berada pada smartphone. Dimana penentuan posisi seseorang berdasar sinyal gps smartphone yang diterima dari satelit. Dengan kata lain satelit akan mentransmisikan pengidentifikasi sinyal, posisi dan waktu pada smartphone (Schmidt, A. \& Danner, 2010). Kemudia menurut penelitian lain yang dilakukan Welsh et. al., (2012) salah satu pendekatan yang paling mudah dan paling effective menekan biaya adalah geotagging.

Taman Nasional Gungung Ciremai (TNGC) secara geografis berada di kordinat $108^{0} 20^{\prime} \mathrm{BT}-108^{0} 40 \mathrm{BT}$ dan $6^{0} 40$ LS $-6^{0} 58$ LS. Kondisi kawasan TNGC pada umumnya berombak, berbukit, dan bergunung dengan membentuk kerucut di bagian puncak dengan ketinggian $3.078 \mathrm{mdpl}$ dan merupakan gunung tertinggi di Jawa Barat. Kondisi topografi Gunung ciremai bervariasi mulai dari landai sampai curam. Kemiringan lahan yang termasuk landau $\left(0^{0}-8^{0}\right)$ hanya $26,52 \%$ dan diatas $8^{0}$ sebesar $73,48 \%$. Luas keseluruhan kawasan TNGC \pm 15.500 Ha terbagi di dua wilayah seluas $6.800,13 \mathrm{Ha} \mathrm{di}$ Kabupaten Majalengka dan 8.699,87 Ha di Kabupaten Kuningan. Secara administrative pemerintahan wilayah TNGC meliputi 2 wilayah kabupaten yaitu sebelah barat termasuk Kabupaten Majalengka, dan sebelah timur termasuk Kabupaten Kuningan dengan 7 kecamatan yang terdiri dari 25 desa di Kabupaten Kuningan dan 20 desa yang ada di 7 kecamatan di Kabupaten Majalengka (BTNGC, 2010)

Kawasan gunung ciremai ditetapkan menjadi taman nasional melalui Keputusan Mentri Kehutanan Nomor 424/Menhut-II/2004 tanggal 19noktober 2004. Pertimbangan penetapannya adalah kawasan Gunung Ciremai merupakan kawasan ekosistem hutan alam dengan klasifikasi zona bawah $(<1.400 \mathrm{mdpl})$, zona tengah $(1.400-2.400 \mathrm{mdpl})$ dan zona puncak (> 2.400 mdpl). Pertimbangan lain penetapan sebagai Taman Nasional karena kawasan tersebut memiliki keanekaragaman hayati yang tinggi dan 
JURNAL NUANSA INFORMATIKA

Volume 14 Nomor 1, Januari 2020

merupakan daerah resapan air bagi kawasan dibawahnya. Sebelum menjadi Taman Nasional, kawasan Gunung Ciremai merupakan hutan lindung dan hutan produksi yang dikelola oleh perum perhutan (Hermawan et.al., 2005)

Kawasan TNGC telah memberikan jasa lingkungan bagi masyarakat luas dalam bentuk jasa lingkungan air dan jasa wisata. Jasa lingkungan tersebut selama ini di gunakan oleh masyarakat dan pemerintah daerah baik di wilayah Kuningan maupun Majalengka. Secara nyata pemanfaatan jasa lingkungan tersebut telah berkontribusi penting bagi pendapatan asli daerah pemerintah daerah dan juga taraf hidup masyarakt terutama kelompok - kelompok pengelola wisata.

Taman nasional merupakan kawasan hutan konservasi alam yang memiliki tujuan untuk perlindungan, penelitian dan pemanfaatan. Selama ini TNGC memiliki permasalahan berupa ancaman kerusakan dari sekitar masyarakat yang berdekatan dengan kawasan TNGC berupa penggarapan lahan, pencurian kayu, penambangan liar, perburuan liar, pembakaran hutan, dan lain-lain yang erat kaitannya dengan faktor sosial ekonomi masyarakat desa. Mekasnisme pelaporan dan pencatatan ancaman kerusakan di BTNGC memang sudah ada yaitu avenza map tetapi aplikasi ini hanya bisa dilakukan oleh petugas BTNGC dan aplikasi ini belum bisa diintregrasikan pada sistem yang sedang berjalan sedangkan pelaporan dari masyarakat sendiri masih menggunakan cara manual yaitu dengan mencatat setiap kejadian.

\section{Metode Penelitian}

\section{System Development Life Cycle}

Sebelum membangun sistem informasi, kita harus mengetahui metodologi pengembangan yang tepat
p-ISSN : 1858-3911, e-ISSN : 2614-5405

https://journal.uniku.ac.id/index.php/ilkom

bagi sistem. Pendekatan yang dapat digunakan untuk melakukan pengembangan sistem informasi adalah pendekatan System Development Life Cycle (SDLC) prediktif, pendekatan Adaptif dan Unified Process (UP). Selain itu berkembang paradigm baru dalam pengembangan sistem informasi yaitu Agile Methodology yang terdiri dari Extreme Pragramming (XP) dan Scrum (Satzinger, et, al, 2007

\section{Tahapan SDLC Extreme Programming}

Terdapat lima tahapan utama dalam pengembangan sistem informasi dengan menggunakan Extreme programming (XP) yaitu (Abrahamson, 2002) : Eksplorasi, planning, iterasi pengembangan sistem (analisis, desain, testing), produksi, maintenance, dan mengakhiri proyek dengan mengeluarkan final release. Akhir disetiap fase yang dikembangkan merupakan milestone atas fase tersebut sebelum bergerak ke fase berikutnya. Adapun tahapan-tahapan pengembangan sistem dengan menggunakan XP dapat dilihat pada gambar 7 :

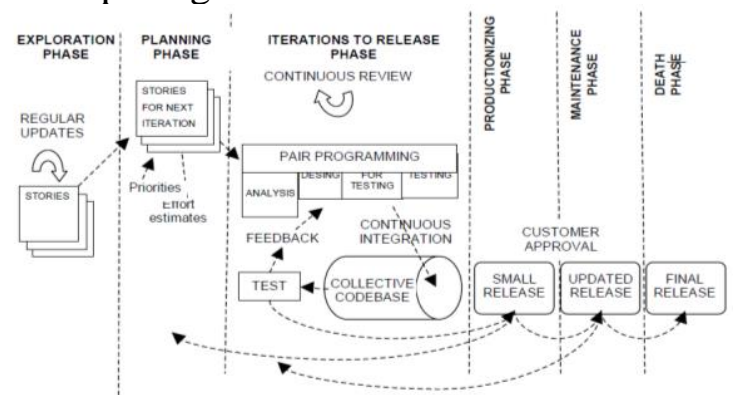

Gambar 2.4. Tahapan Extreme Programming (Abrahamsson, 2002)

Secara rinci tahapan-tahapan XP adalah sebagai berikut :

a. Tahapan Ekplorasi

Pada tahap ini calon pengguna sistem menuliskan kebutuhan-kebutuhan informasi yang akan dicover didalam sistem untuk release pertama. Masingmasing cerita yang dituliskan oleh pengguna kemudian dibuat menjadi 
JURNAL NUANSA INFORMATIKA

Volume 14 Nomor 1, Januari 2020

sebuah modul program. Di lain sisi, tim yang lain mengidentifikasi teknologi dalam pelaksanaan proyek. Tahap ini dapat dilaksanakan dalam beberapa minggu, tergantung pada kerumitan sistem yang akan dibangun. Hasil yang diinginkan pada tahap ini adalah berupa

1. Dokumentasi atas Visi dan ruang lingkup pekerjaan

2. Dokumentasi penaksiran resiko

3. Dokumentasi struktur proyek yang akan dikembangkan

4. Dokumentasi teknologi yang akan digunakan

\section{b. Tahapan Planning}

Pada fase planning, yang berorientasi kepada analisa dan desain sistem, yang didalamnya berisikan kebutuhan akan analisa atas kebutuhan bisnis, kebutuhan pengguna, kebutuhan operasi, dan kebutuhan sistem. Setelah tahapan atas, tahapan ini dilalui, tim pengembang akan menghasilkan :

1. Spesifikasi fungsional atas suatu sistem

2. Perencanaan manajemen resiko pada suatu sistem

3. Perencanaan jadwal pelaksanaan proyek

c. Iterasi Pengembangan Sistem

Pada tahapan ini terdiri dari beberapa iterasi pengembangan sistem yang akan dikembangkan. Mulai dari rilis pertama hingga sistem dapat diterima dan dapat di implementasikan secara penuh. Tahapan-tahapan dalam iterasi ini terdiri dari :

1. Tahap analisis

2. Tahap desain

3. Tahap pengujian (testing)

d. Peluncuran Rilis Akhir Perangkat Lunak

Tahapan ini merupakan sesi akhir dalam pengembangan sistem dengan menggunakan XP. Sistem yang telah di
p-ISSN : 1858-3911, e-ISSN : 2614-5405

https://journal.uniku.ac.id/index.php/ilkom

uji kemudian di implementasikan sesuai dengan kebutuhan client. Perangkat lunak yang diaplikasikan merupakan rilis akhir, hasil dari iterasi dan perbaikan dari versi-versi sebelumnya Adapun langkah-langkah yang ditempuh dalam menyelesaikan penelitian sebagai mana terlihat pada gambar di bawah ini :

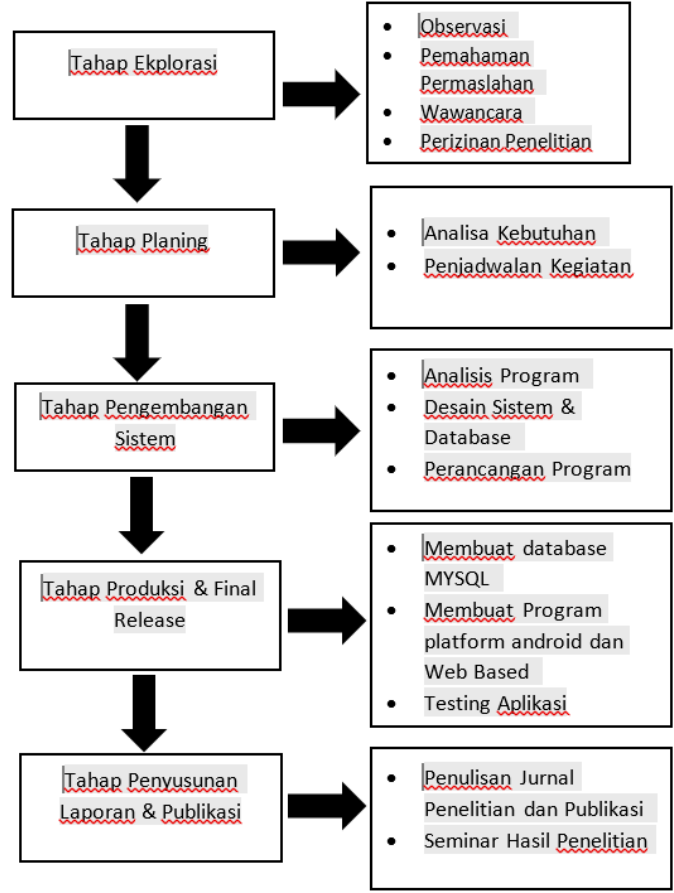

Gambar1. Skema Metodologi Penelitian

\section{a. Tahap Eksplorasi}

Pada tahapan ini peneliti telah mengobservasi tempat penelitian, serta pemahaman masalah yang di hadapi oleh pihak BTNGC. Dalam proses pemahaman masalah peneliti melakukan proses wawancara berkaitan dengan masalah pelaporan dan pencatatan aktifitas kegiatan hutan baik yang dilakukan oleh masyarakat maupun staf atau petugas lapangan BTNGC. Para petugas BTNGC memang sudah mempunyai aplikasi untuk mencatat aktifitas tersebut, tetapi aplikasi tersebut belum bisa diintregrasikan pada sistem yang berjalan dan untuk pelaporan dari masyarakat masih menggunakan cara manual yaitu mencatat kejadian - 
JURNAL NUANSA INFORMATIKA

Volume 14 Nomor 1, Januari 2020

kejadian yang nantinya akan di laporan kolektif dari semua wilayah yang ada di TNGGC. Proses manual tadi mengakibatkan terhambatnya laporan kejadian - kejadian ke pihak BTNGC. Pada tahap ini juga peneliti melakukan perijinan terhadap lokasi - lokasi yang akan dijadikan sebagai objek penelitian diantaranya : 1.Buper Palutungan, 2.Telaga Nilem, 3.Situ Cicereum, 4.Lembah Singkup, 5.Lambosir, 6.Buper Cibunar, 7.Balong Dalem, 8.Tejo Layar, 9.Buper Ipukan, 10.Pemandian Cigugur,

\section{b. Tahap Planing}

Pada tahapan ini adalah proses analisa kebutuhan yakni kebutuhan data dan kebutuhan peralatan penunjang penelitian. Untuk kebutuhan data peneliti telah mendapatkan data berkaitan dengan pengelompokan atau kriteria - kriteria yang berkaitan dengan masalah pelaporan dan pencatatan aktivitas kegiatan hutan, diantaranya :

1. Ancaman

2. Kebakaran dan Bencana,

3. Pal Batas dan Potensi Alam,

4. Air,

5. Fauna,

6. Flora,

7. Penyuluhan,

8. Sosek,

9. Wisata

Kebutuhan yang lain yakni peralatan penunjang penelitian yaitu sebuah smartphone untuk menjalankan aplikasi dan mengambil foto lokasi. Kemudian alat yang kedua yaitu GPS Garmin dimana alat ini dibutuhkan untuk menguji kordinat yang nantinya akan di uji keakuratan yang ada pada aplikasi.

\section{c. Tahap Pengembangan Sistem}

Pada tahap ini peneliti melakukan analisis program, desain sistem dan database dan perancangan program.

- Analisis Program

Pada tahapan ini peneliti melakukan pengujian terhadap sistem
p-ISSN : 1858-3911, e-ISSN : 2614-5405

https://journal.uniku.ac.id/index.php/ilkom

yang berjalan di BTNGC, dari hasil ini didapat aplikasi yang berjalan yaitu berbasis web. Dari hasil analisis tersebut peneliti akan menyesesuaikan beberapa konten yang bisa terintregrasi dengan sistem yang akan di bangun yakni program yang berjalan pada flatfrom mobile atau android.

- Desain Sistem dan Database

Proses desain sistem adalah proses selanjutnya setelah tahap analisis, dimana tahap ini adalah mendefinisikan kebutuhan - kebutuhan funsional, persiapan untuk rancang bangun implementasi serta menggambarkan bagaimana suatu system dibentuk. Salah satunya adalah perancangan use case diagram, dan berikut adalah gambar use case nya:

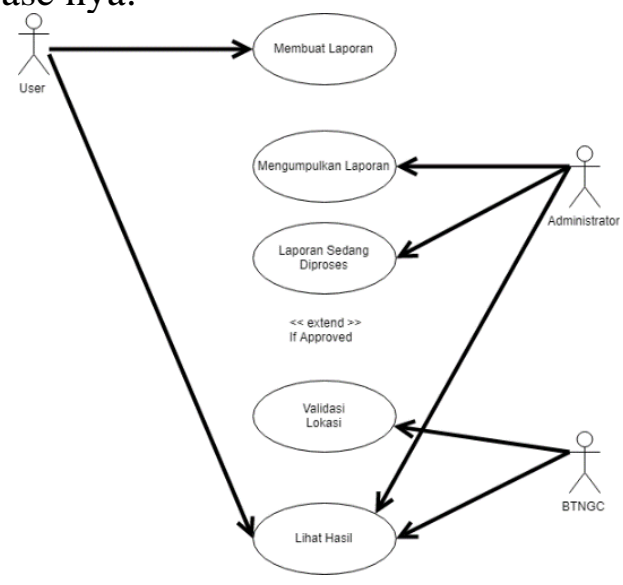

Gambar 2 Use case Diagram SISP2AKH

Keterangan gambar diatas :

Terdapat 3 entitas atau pengguna yaitu User dalam hal ini bisa masyarakat atau petugas BTNGC, kemudian Administrator dan BTNGC.

User : entitas ini akan membuat laporan serta dapat melihat hasil dari pelaporan pelaporan yang sudah di validasi dan dilakukan penindakan oleh pihak BTNGC.

Administrator : entitas ini bertugas sebagai petugas approve laporan laporan yang nantinya akan dilakukan proses validasi lokasi oleh pihak Balai. 
BTNGC : entitas ini betugas proses pengecekan lokasi setelah mendapat proses approvement dari administrator

\section{HASIL DAN PEMBAHASAN}

Pada implementasi sistem ini terdapat dua aplikasi yaitu aplikasi yang berbasis android dan aplikasi yang berbasis web yang di integrasikan pada sistem yang berjalan yaitu aplikasi Sitroom TNGC. Pada Sistem Pencatatan dan Pelaporan Aktifitas Kegiatan Hutan atau di singkat SISPPAKH terdapat dua tipe user pengguna yakni masyarakat dan petugas TNGC. Pengguna atau user masyarakat untuk bisa mengakses dan melaporakan aktifitas hutan, terlebih dahulu harus melakukan registrasi dengan email yang valid, sedangkan untuk user petugas sendiri di tambahkan sendiri oleh pihak admin dari TNGC.

\section{a. Antarmuka Berbasis Android}

Untuk aplikasi android terdapat beberapa menu yang dapat diakses oleh masyarakat dan petugas, diantaranya :

a. Login Aplikasi dan Registrasi Aplikasi

Pada saat pertama kali menjalankan aplikasi anda harus login terlebih dahulu, jika belum mempunyai akun aplikasi ini, terlebih dahulu anda melakukan proses registrasi dengan mengisikan username, password dan alamat email. Setelah itu anda login dengan akun yang sudah diregistrasi. Berikut adalah tampilan login dan registrasi :

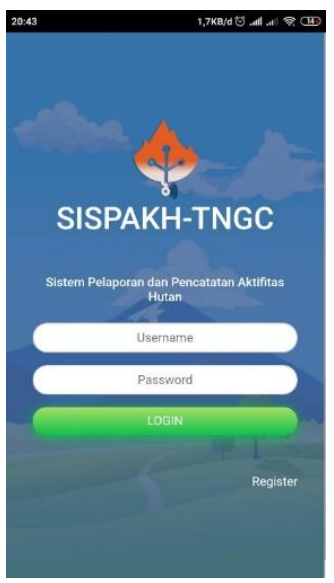

Gambar 3. Login Aplikasi

b. Halaman Beranda dan Menu Aplikasi

Pada saat aplikasi pertama kali dijalankan halaman ini yang ditampilkan, dimana terdapat beberapa informasi terkait laporan - laporan yang telah di upload baik dari masyarakat atau petugas TNGC. Adapun beberapa tombol menu dalam aplikasi android ini yaitu Beranda, Berita, User, Laporan, Wisata dan Keluar. Berikut adalah tampilan beranda dan tombol menu aplikasi :

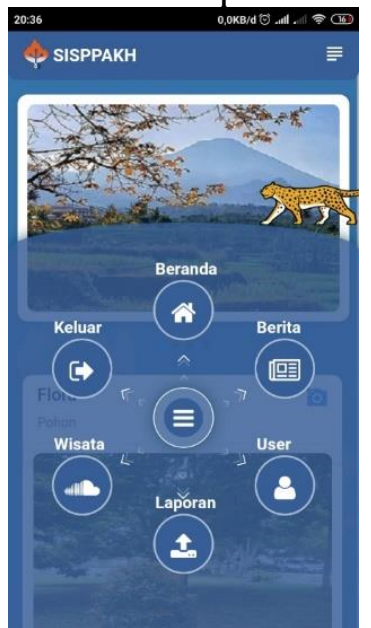

Gambar 4. Tombol Menu Aplikasi

c. Menu Laporan

Pada halaman ini merupakan bagian inti dari aplikasi, dimana dalam halaman ini terdapat langkah - langkah 
JURNAL NUANSA INFORMATIKA

Volume 14 Nomor 1, Januari 2020

dalam proses pelaporan. Pada gambar 4.7 langkah pertama dimulai dengan pengambilan gambar, baik oleh kamera atau upload image yang sudah terdapat informasi gps. Pada gambar 4.9 langkah kedua yaitu pemilihan kategori berdasarkan laporan yang dikirimkan. Pada gambar 4.10 langkah ketiga adalah pengisian deskripsi kejadian dan menekan tombol submit untuk melakukan pelaporan. Berikut tampilan dari langkah - langkah laporan :

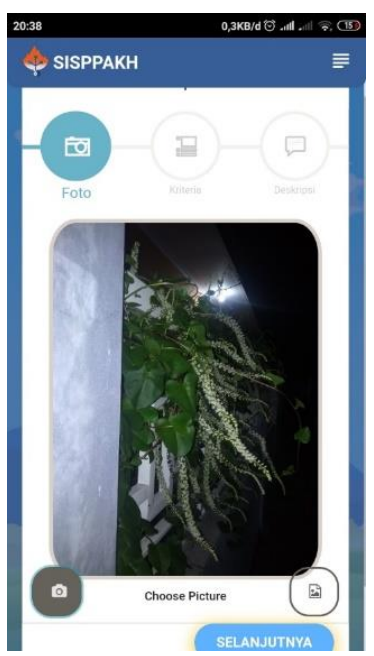

Gambar 5. Hasil Pengambilan dari

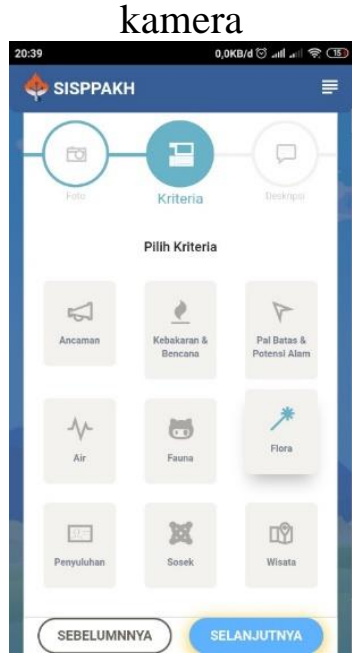

Gambar 6. Pemilihan Kriteria

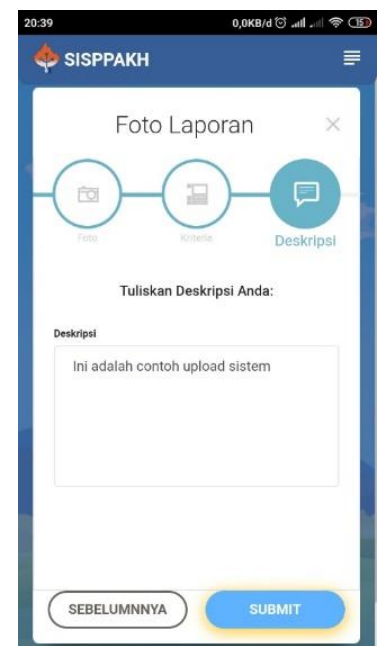

Gambar 7. Deskripsi Laporan

\section{b. Antamuka Berbasis Web}

Sistem SITROOM adalah aplikasi yang sudah berjalan di TNGC, sistem ini berkaitan dengan hal - hal informasi TNGC yang bersipat public, pada penelitian ini sistem yang dibuat akan diintregrasikan pada sistem yang telah ada yaitu Sitroom. Proses intrregasi ini supaya mempermudah dalam hal pengelolaan satu pintu. Sistem berbasis web ini diperuntukan untuk bagian approval atau tindak lanjut dari laporan laporan yang dikirimkan melalui aplikasi android serta untuk melihat visualisasi dalam bentuk peta. Berikut adalah tampilan aplikasi berbasis web :

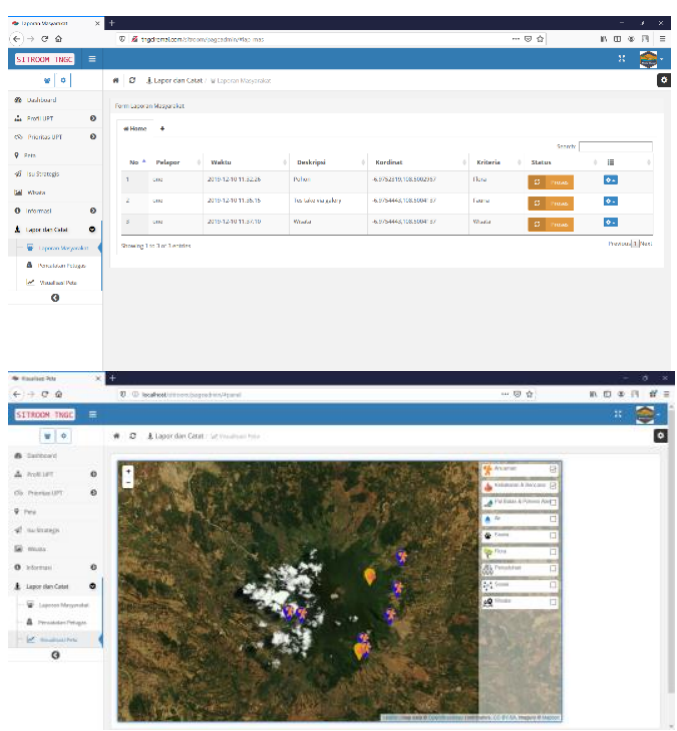




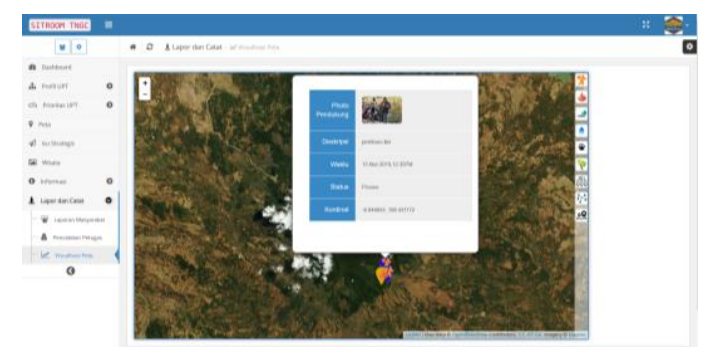

Gambar 8.

\section{KESIMPULAN}

Berdasar uraian yang telah dibahas pada bab - bab sebelumnya serta hasil pembahasan dari Sistem Informasi Pelaporan dan Pencatatan Aktifitas Kegiatan Hutan di Taman Nasional Gunung Ciremai Berbasis Image Geotagging, maka dapat diambil kesimpulan :

1. Aplikasi ini mempermudah dan membantu pihak balai TNGC dalam pengadministrasian pelaporan dari masyarakat, yang selama ini proses pelaporan masih manual.

2. Dalam aplikasi ini pihak Balai bisa dengan mudah memproses tindak lanjut apabila terdapat laporan yang dapat menggangu kelestarian TNGC. Serta bisa mengevaluasi berdasar kejadian - kejadian atau pelaporan, sehingga pihak BTNGC bisa lebih memprioritaskan daerah mana yang rentan atau sering melakukan ancaman terhadap Kawasan TNGC.

3. Mempermudah masyarakat dalam hal proses pelaporan atau aktifitas yang terjadi di Kawasan TNGC. Aplikasi ini diharapkan menjadi sarana aktif untuk kegiatan masyarakat sadar hutan.

4. Dalam aplikasi ini masih ada kekurangan yaitu belum adanya fitur untuk memfilter kejadian diluar Kawasan TNGC, jadi pihak BTNGC harus melihat laporan berdasar Kawasan TNGC untuk proses approvement.

\section{DAFTAR PUSTAKA}

p-ISSN : 1858-3911, e-ISSN : 2614-5405

https://journal.uniku.ac.id/index.php/ilkom

Alter, Steven. 1992. Information System: A Management Presvective. The Benjamin / Cummings Publishing Company, Inc

Bodnar, George H., Hopwood, William S. 1993. Acounting Information System. $5^{\text {th }}$ Edition, PrentienceHall, Inc

BTNGC. 2010. Rencana strategis Taman Nasional Gunung Ciremai tahun 2010-2014. Balai Taman Nasional Gunung Ciremai, Kuningan.

Fletcher, S., France, D., Moore, K. \& Robinson, G. 2003. Technology before pedagogy? A GEES C\&IT perspective, Planet, 5, pp. 52-5

Gelinas, Ulric J., Oram, Allan E., Wiggins, William P. 1990. Accounting Information System. PWS-KENT Publishing Company

Hermawan, T.T., A. Affianto, A. Susanti, E. Soraya, W. Wardhana, dan S. Riyanto, S. .2005. Model pemanfaatan lahan di Taman Nasional Gunung Ciremai. Institute for Forest and Environment (INFRONT), Yogyakarta

Hall, James A. 2001. Accounting Information Systems $3^{\text {rd }}$ Edition, South Western College Publishing.

Kadir, Abdul .2003. Pengenalan Sistem Informasi, Penerbit Andi, Yogyakarta

Kadir, Abdul .2014. Pemograman Aplikasi Android. Penerbit Andi, Yogyakarta

Luo, J., Joshi, D., Yu, J., Gallagher, A. \& Gallagher, A. .2011. Geotagging in multimedia and computer vision: A survey, Multimedia Tools and Applications, 51(1), pp. 187-211.

Mannino, M.V.2001. Database Application Development and Design. McGraw-Hill. Singapore 
JURNAL NUANSA INFORMATIKA

Volume 14 Nomor 1, Januari 2020
p-ISSN : 1858-3911, e-ISSN : 2614-5405

https://journal.uniku.ac.id/index.php/ilkom

Safaat, $\quad$ H Nazruddin .2012.

Pemrograman aplikasi mobile smartphone dan tablet PC Berbasis android, Informatika, Bandung

Satzinger, John, et al. 2007 System Analys and Design, $4^{\text {th }}$ Ed., Thomson Course tech., Canada.

Schmidt, A. and Dannert., .2010. Positioning Technologies and Mechanisms for mobile Devices, Semin. Master Modul. SNET2 (TU-Berlin, ed.)

Turban, Efraim., McClean, Ephraim., Wetherbe, James. 1999. Information Technology for Management Making Connections for Strategis Advatange. $2^{\text {nd }}$ Edition, John Willey \& Son, Inc.

Welsh, K. E., France, D., Whalley, W. B., and Park, J. R. 2012. Geotagging photographs in student fieldwork, Journal of Geography in Higher Education.

Wilkinson, Joseph W. 1992. Accounting and Information Systems. John Willey \& Sons, Inc 